\section{MARCH 2010}

\section{Cardiothoracic Surgery \\ Symposium}

The 30th Annual Cardiothoracic Surgery Symposium will be held March 4-7, 2010, at The Newport Beach Marriott Hotel and Marina, San Diego, California, USA. Abstract submission deadline: February 1, 2010. For information, contact: Susan Westwood, San Diego Cardiothoracic Surgery Symposium, 793-A E Foothill Boulevard, \#119, San Luis Obispo, CA 93405 (telephone: 1-805-5413118; Fax: 1-716-809-4082; E-mail: susan@amainc.com). Additional information: http://www.amainc.com/ cref_cardiothoracic.html

\section{General Thoracic Surgical Club}

General Thoracic Surgical Club will be held March 11-14, 2010, at the LaCosta Resort and Spa, Carlsbad, California, USA. CME available. For information, contact: Bonnie Lemmerman or Carla MacLean, General Thoracic Surgical Club, Mayo Clinic, 200 First Street SW, Rochester, MN 55905, USA (telephone: +1-507-538-4969; Fax:+1-507284-0058; E-mail: blemmerman@ mayo.edu or cmaclean@mayo.edu).Additional information: http://www.gtsc.org/

\section{ESTS School of Thoracic Surgery}

The ESTS School of Thoracic Surgery will be held March 17-21, 2010, in Antalya, Turkey. For registration and accommodation, contact: Mondial Congress and Events, Mondial GmbH \& Co. KG, Operngasse 20b, 1040 Vienna, Austria (Phone:

\footnotetext{
Announcements of major meetings and other significant activities must be received at least 8 weeks before the desired month of publication. Information will be limited to title of meeting, date, place, and an address to obtain further information. Send announcements to Ryan Walther, Managing Editor, The Journal of Thoracic and Cardiovascular Surgery, 900 Cummings Center, Suite 221-U, Beverly, MA 01915 (E-mail: rwalther@prri.com).
}

+43 158804 0; Fax: +43 158804 0 185; E-mail: ests2010@mondialcongress.com). For information, contact: Scientific Secretariat, European Society of Thoracic Surgeons, PO Box 159, Exeter EX2 5SH, United Kingdom (Phone: +44 1392 430671; Fax: +44 1392 430671; E-mail: sue@ests.org.uk; Web site: http:// www.ests.org). Additional information: http://www.estsschool.org

\section{5th Annual Update on} Cardiopulmonary Bypass

The 15th Annual Update on Cardiopulmonary Bypass will be held March 21-26, 2010, at the Fairmont Chateau, Whistler, British Columbia, Canada. For more information, please go to: http://www.scahq.org.

\section{APRIL 2010}

The Houston Aortic Symposium: Frontiers in Cardiovascular Diseases

The Houston Aortic Symposium: Frontiers in Cardiovascular Diseases, The Third in the Series will be held April 8-10, 2010, at The Westin Oaks Hotel, Houston, Texas, USA. Abstract submission deadline: February 26, 2010. For information, contact: Promedica International, 2333 State Street, Suite 203 (telephone: 1-760-7202263; Fax: 1-760-720-6263; E-mail: HAS2010@promedicacme.com). Addi tional information: http://www.prome dicacme.com/

\section{European Society for}

Cardiovascular Surgery-Heart and Health Foundation of Turkey

The 59th International Congress of the European Society for Cardiovascular Surgery in conjunction with the 6th Congress of Update in Cardiology and Cardiovascular Surgery (UCCS) organized by Heart and Health Foundation of Turkey (HHFT) will be held April 15-18, 2010, at the Sheraton Cesme Hotel, Izmir, Turkey. All participants who registered for only the 59th ESCVS International Congress can also get free registration for the 6th Congress of Update in Cardiology and Cardiovascular Surgery. Abstracts for the ESCVS International Congress will be published in Interactive CardioVascular and Thoracic Surgery Journal. All authors with accepted abstracts are strongly recommended to submit the full manuscript of their work to the Interactive CardioVascular and Thoracic Surgery Journal, the ESCVS official journal. For information, contact: Prof Oztekin Oto, MD, FESC, FACC, Chairman of Local Organization Committee President of Congress. Additional information: http://www.tksv.org/

\section{Aortic Symposium 2010}

Aortic Symposium 2010 will be held April 29-30, 2010, at the Sheraton New York Hotel and Towers, New York City, New York, USA. Course Directors: Randall B. Griepp, MD, Mount Sinai School of Medicine and Steven L. Lansman, MD, Westchester Medical Center. Abstract submission deadline: December 11, 2009. Visit www.aats.org to learn more about submitting.

\section{MAY 2010}

\section{AATS 90th Annual Meeting}

The AATS 90th Annual Meeting will be held May 1-5, 2010, at the Metro Toronto Convention Centre, Toronto, Ontario, Canada. For more information: http://www.aats.org

\section{8th European Conference on General Thoracic Surgery}

The 18th European Conference on General Thoracic Surgery will be held May 30-June 2, 2010, at Feria de Valladolid, Avenida Ramón Pradera s/n, 47009 Valladolid, Spain. For registration and accommodation, contact: Mondial Congress and Events, Mondial $\mathrm{GmbH} \& \mathrm{Co}$. KG, Operngasse 20b, 1040 Vienna, Austria (Phone: +431 58804 0; Fax: +43 1588040 185; Email: ests2010@mondial-congress.com). 
For information, contact: Scientific Secretariat, European Society of Thoracic Surgeons, PO Box 159, Exeter EX2 5SH, United Kingdom (Phone: +44 1392 430671; Fax: +44 1392 430671; E-mail: sue@ests.org.uk; Web site: http://www.ests.org). Additional information: http://www.estsmeetings. org/2010/

\section{JUNE 2010}

\section{European Society for Surgical Research (ESSR) 45th Annual Congress}

The 45th Annual Meeting of the European Society for Surgical Research (ESSR) will be held June 9-12, 2010, at Centre Medical Universitaire, Geneva, Switzerland. Extended abstract submission deadline: January 10, 2010. For information, contact: Mustafa Cikirikcioglu, MD, PhD, Division of Cardiovascular Surgery, Department of Surgery, University Hospitals of Geneva Rue Gabrielle-Perret-Gentil 4, CH-1211 Genve 14, Switzerland (telephone: +41 2237276 63; Fax: +41 2237276 34; E-mail: mustafa. cikirikcioglu@hcuge.ch; Web site: www.essr2010.ch). Additional information: http://www.ctsnet.org/file/ ESSR2010announcement.pdf

\section{ISMICS 12th Annual Scientific Meeting}

The International Society for Minimally Invasive Cardiothoracic Surgery (ISMICS) 12th Annual Scientific Meeting will be held June 16-19, 2010, at the InterContinental Hotel, Berlin, Germany. The abstract submission site opens in early September 2009. For information, contact: EJ Weldon, 900 Cummings Center (telephone: +1 978-927-8330; E-mail: ISMICS@prri.com). Additional information: http:// www.ismics.org/

\section{Eighth International Symposium on Redo Cardiac Surgery in \\ Adults}

The Eighth International Symposium on Redo Cardiac Surgery in Adults will be held June 26-27, 2010, in Pittsburgh, Pennsylvania, USA. For more information, contact: Sharon Slomka, 5200 Centre Avenue, \#715, Pittsburgh, PA 15232 (telephone: 412-623-3140; fax: 412-6236431; E-mail: slomkasm@upmc.edu).

\section{SEPTEMBER 2010}

5th International Meeting of the Onassis Cardiac Surgery Center

The 5th International Meeting of the Onassis Cardiac Surgery Center: Cur- rent Trends in Cardiac Surgery and Cardiology will be held September 16-18, 2010 (NOTE DATE CHANGE) at the Eugenides Foundation Congress Center, Athens, Greece. Revised Abstract submission deadline: March 8, 2010. For information, contact: Liana Iliopoulou, Triaena Tours \& Congress, 206 Sygrou Avenue, 17672 Athens (Kallithea) (telephone:+30 2107499353 ; Fax:+30 210 7705752; E-mail: lianae@triaenatours. gr). Additional information: http:// www.ocsc2010.gr/

\section{ESTS School of Thoracic \\ Surgery}

The ESTS School of Thoracic Surgery will be held September 27-28, 2010, in Elancourt, France. For registration and accommodation, contact: Mondial Congress and Events, Mondial GmbH \& Co. KG, Operngasse 20b, 1040 Vienna, Austria (Phone: +43 158804 0; Fax: +43 158804 0 185; E-mail: ests2010@mondialcongress.com). For information, contact: Scientific Secretariat, European Society of Thoracic Surgeons, PO Box 159, Exeter EX2 5SH, United Kingdom (Phone: +44 1392 430671; Fax: +44 1392 430671; E-mail: sue @ests.org.uk; Web site: http:// www.ests.org). Additional information: http://www.estsschool.org 